九州大学学術情報リポジトリ

Kyushu University Institutional Repository

\title{
A Ricin B chain-Ribonuclease A Hybrid Protein : A new tool for introduction of a foreign protein into targeted cells
}

Ishiguro, Masatsune

Laboratory of Protein Chemistry \& Engineering, Department of Genetic Resources Technology, Facultry of Agriculture, Kyushu University

Hisako, Takeshi

Department of Biochemistry, School of Clinical Pharmaceutical Sciences, Nagasaki University

Sakakibara, Ryuzo

Department of Biochemistry, School of Clinical Pharmaceutical Sciences, Nagasaki University

Yamaguchi, Junji

Laboratory of Protein Chemistry and Engineering, Department of Genetic Resources Technology, Graduate School of Bioresource and Bioenvironmental Sciences, Kyushu University

他

https://doi.org/10.5109/24450

出版情報: 九州大学大学院農学研究院紀要. 46 (2)，pp.367-379，2002-02-28. Kyushu University バージョン：

権利関係 : 


\title{
A Ricin B chain-Ribonuclease A Hybrid Protein (A new tool for introduction of a foreign protein into targeted cells)
}

\author{
Masatsune ISHIGURO**, Takeshi HISAKO*, Ryuzo SAKAKIBARA*, Junji \\ YAMAGUCHI***, and Yoichi ASO
}

\author{
Laboratory of Protein Chemistry \& Engineering, Department of Genetic Resources Technology, \\ Faculty of Agriculture, Kyushu University, 6-10-1 Hakozaki, Higashi-ku, Fukuoka 812-8581, \\ and *Department of Biochemistry, School of Clinical Pharmaceutical Sciences, \\ Nagasaki University, 1-14 Bunkyo-machi, Nagasaki 852, JAPAN. \\ (Received October31, 2001 and accepted November 20, 2001)
}

\begin{abstract}
A hybrid protein was synthesized by connecting bovine ribonuclease A (RNase A), an enzyme, and $B$ chain of ricin, a toxic lectin from castor bean seeds, with a disulfide bridge. The preparation purified was revealed to contain one mole of RNase A and one mole of ricin B chain. The ricin B-RNase A hybrid was tested for cell binding, cellular uptake, and intoxication in four kinds of cells, rat liver and testis Leydig cells (normal and primarily cultured cells), and HeLa and BeWo cells (transformed cells).

The ricin B-RNase A hybrid inhibited cellular protein synthesis equally in all four cells, while incubation of each cell mentioned above with RNase A or ricin B chain alone neither gave effect on cellular protein synthesis nor cell viability. This result inferred that the ricin B-RNase A hybrid first bound to the cell surface, internalized followed by the release of RNase $A$ from the hybrid, resulting in the destruction of RNAs which play important roles in cellular protein synthesis. The degree of internalization of the ricin B-RNase A hybrid into cells was almost equal in four types of cells, about $10 \%$ of the bound hybrid. However, this value was about $1 / 3 \sim 1 / 2$ that of ricin, a toxic lectin composed of $\mathrm{A}$ and $\mathrm{B}$ chains. From these results, ricin B-containing hybrid may be used as a universal tool to deliver a biologically active protein to a large number of different cells.
\end{abstract}

\section{INTRODUCTION}

In our previous studies we reported on synthetic hybrids composed of human chorionic gonadotropin (hCG) and either A or B chain of ricin or horseradish peroxidase (HRP), which have been employed as hormone analogs in order to clarify the interaction of the hormone and its target cells (Sakai et al., 1989, 1991; Ohwaki et al., 1994). It was revealed that hybrids containing hCG and either ricin A or B chain exhibited hCG hormonal activity toward rat Leydig cells measured with the increases in cAMP and testosterone. Especially, hCG-ricin B hybrid was shown to possess almost equal activity even though the original hCG molecule was modified with ricin B resulting in a sterically larger molecule. Hybrids composed of either $\alpha$ or $\beta$ subunit of hCG and ricin B chain also stimulated the production of testosterone in Leydig cells though their potencies were as weak as a two-hundredth of that of hCG. It was speculated from these results that for the

\footnotetext{
*** Laboratory of Protein Chemistry \& Engineering, Department of Genetic Resources Technology, Graduate School of Bioresource and Bioenvironmental Sciences, Kyushu University, Fukuoka 812-8581, Japan

** Corresponding author: Fax number: 092-642-3051, E-mail: ishiguro@agr.kyushu-u.ac.jp
} 
manifestation of hormonal activity of hCG three kinds of binding between a hormone and rat Leydig cells would participate as follows: binding of the hCG moiety to its receptor, binding of the $\mathrm{B}$ chain moiety to terminal galactose residues attached to the cell-surface membrane, and binding of a lectin-like protein(s) in the cell-surface membrane to oligosaccharides of the B chain moiety.

It was evident from results mentioned above that the ricin $B$ chain possesses such an unique character as compensating the hormonal activity of hCG-B hybrid in addition that the $\mathrm{B}$ chain in the original ricin molecule plays important role in manifesting ricin cytotoxicity towards a large number of eukaryotic cells. In order to clarify the mechanism of ricin cytotoxicity in detail as well as to explore a possible utilization of the $\mathrm{B}$ chain for the introduction of foreign molecule( $\mathrm{s}$ ) into the desired cells, a hybrid protein consisting of ricin B chain cross-linked with bovine pancreatic ribonuclease A (RNase A) was synthesized and its cytotoxicity, binding to cells and internalization into cells have been determined. Results presented in this paper have shown that a hybrid containing ricin $B$ chain could bind to various types of cells and exhibited cytotoxicity which implied that $B$ chain could help internalization of RNase A, a foreign protein to cells. A relevant discussion relating to the cytotoxic mechanism of ricin is also given.

\section{MATERIALS AND METHODS}

\section{Materials.}

Ricin D was prepared from Chinese castor beans according to the method of Hara et al. (Hara et al., 1974) and ricin B chain was obtained as described by Fulton et al. (Fulton et al., 1986). The extinction coefficients $\left(\mathrm{E}_{1 \%, 280 \mathrm{~mm}}\right)$ used to calculate protein concentrations for ricin D and ricin B chain were 14.4 and 14.0, respectively (Hara et al., 1975). N-Succinimidyl-3-(2-pyridyldithio)propionate (SPDP) was purchased from Pharmacia. ECONOFRUOL from Daiichi Kagaku Yakuhin, trypan blue, Weymouth and D-MEM media from Gibco, respectively. $\left.\mathrm{Na}{ }^{125 \mathrm{I}}\right] \quad(0.644 \mathrm{MBq} / \mathrm{mg})$ and $\left.{ }^{[55} \mathrm{S}\right]$ Methionine/Cysteine (Met/Cys) $(1.85 \mathrm{MBq} / \mathrm{ml})$ or $\left[{ }^{14} \mathrm{C}\right]$ Leucine $(1.85 \mathrm{MBq} / \mathrm{ml})$ were from Amersham. Bovine serum albumin (BSA) and bovine pancreatic ribonuclease A (RNase A) were obtained from Sigma. All other reagents used were of analytical grade and obtained from the commercial sources.

\section{Preparation of a hybrid protein.}

A hybrid protein containing ricin B chain and ribonuclease A (ricin B-RNase A) was prepared with a slight modification of the method described previously (Sakai et al., $1989)$ as follows: RNase A (25.5 mg; $1.9 \mu \mathrm{mol})$ in $1 \mathrm{ml}$ of $0.1 \mathrm{M}$ phosphate buffer containing $0.1 \mathrm{M}$ sodium chloride and $1 \mathrm{mM}$ EDTA ( $\mathrm{pH} 7.6$ ) was incubated with 1.5-fold molar equivalent of SPDP for $30 \mathrm{~min}$ at $25^{\circ} \mathrm{C}$. The reaction was stopped by addition of $1.0 \mu \mathrm{mol}$ of $\mathrm{L}$-glycine solution and the mixture was put on a Sephadex G-25 column to isolate modified RNase A. The average number of 3-(2-pyridyldithio) propionyl (PDP) groups introduced into RNase A per mole was determined to be 1.2 by measurement of the absorbance at $343 \mathrm{~nm}$ due to free pyridine-2-thione generated on reduction of the product with dithiothreitol. In order to synthesize a hybrid, the derivatized RNase A (20.3 mg: $1.5 \mu \mathrm{mol})$ was mixed with the reduced ricin B chain $(9.6 \mathrm{mg}: 0.3 \mu \mathrm{mol})$ at a 
molar ratio of $5: 1$. By incubation for $2 \mathrm{~h}$ at $25^{\circ} \mathrm{C}$, the mixture was gel-filtered through a Sephadex $\mathrm{G}-100$ column in $0.1 \mathrm{M}$ phosphate buffer containing $0.1 \mathrm{M}$ galactose, $\mathrm{pH} 7.6$ to remove an unreacted RNase A. Fractions containing the hybrid were pooled, dialyzed against $5 \mathrm{mM}$ phosphate buffer, $\mathrm{pH} 6.0$, and applied to a $\mathrm{CM}-32$ column which had been equilibrated with the same buffer. After the unreacted B chain was passed through without adsorption to the column, the hybrid was eluted with a linear gradient of $0-0.15 \mathrm{M}$ $\mathrm{NaCl}$ in the same buffer. The purified hybrid was analyzed by SDS-polyacrylamide gel electrophoresis.

Other protein derivatives including hCG-A, hCG-B, ricin A-anti BeWo antibody IgG and liposome-encapusulated ricin D were prepared as described previously (Sakai et al., 1989, 1991, Ohwaki et al., 1994, and Morino et al., 1995), respectively.

\section{Preparation of ${ }^{125} I$-labeled ricin $D$ and ${ }^{125} I$-labeled ricin B-RNase $A$ hybrid.}

[25I]-labeled ricin D and ricin B-RNase A hybrid were prepared according to the method described by Oda et al. (Oda et al., 1979). Specific activities were $1.4 \times$ $10^{6} \mathrm{cpm} / \mu \mathrm{g}$ for $\left.{ }^{[25} \mathrm{I}\right] \mathrm{ricin} \mathrm{D}$ and $4.3 \times 10^{5} \mathrm{cpm} / \mu \mathrm{g}$ for [ ${ }^{[25}$ I]ricin B-RNase A hybrid.

\section{Binding of ricin B-RNase A hybrid toward various types of cultured cells.}

Binding of the ricin B-RNase A hybrid to various types of cultured cells was estimated by the competitive inhibition of binding of ${ }^{125} \mathrm{I}-$-ricin. To HeLa and BeWo cells (each $1.6 \times 10^{4}$ cells/well), and rat Leydig and liver cells $\left(4.8 \times 10^{4}\right.$ cells $/$ well $)$ in 96 titer plate, were added various concentrations of the ricin $\mathrm{B}-\mathrm{RNase} \mathrm{A}$ hybrid, or ricin $\mathrm{D}$ and [ $\left.{ }^{125} \mathrm{I}\right]$ ricin $\mathrm{D}\left(6.0 \times 10^{5} \mathrm{cpm}\right)$, and incubated at $4^{\circ} \mathrm{C}$ for $1 \mathrm{~h}$. HeLa and BeWo cells were washed three times with $10 \mathrm{mM}$ phosphate buffer ( $\mathrm{pH} 7.4$ ) and cell-associated radioactivity was determined with $\gamma$-counter (Aloka ARC-300) after cells were detached from the wells with $0.1 \mathrm{M} \mathrm{KOH}$ solution. Leydig and liver cells were collected on GF/C filter, which had been presoaked in 4\% BSA / $10 \mathrm{mM}$ PBS ( $\mathrm{pH} 7.4$ ), washed three times with $1 \% \mathrm{BSA} / 10 \mathrm{mM}$ PBS ( $\mathrm{pH} 7.4$ ), once with absolute ethanol and dried. Cell-associated radioactivity was determined with an Aloka ARC-300 $\gamma$-counter.

\section{Internalization of the ricin B-RNase A hybrid into cells.}

Four kinds of cells mentioned above were dispensed into 24 wells $\left(8 \times 10^{5}\right.$ cells/well $)$ and incubated with either ${ }^{125} \mathrm{I}$-ricin B-RNase A hybrid or ${ }^{125} \mathrm{I}$-ricin (each $1 \times 10^{-7} \mathrm{M}$ ) at $37^{\circ} \mathrm{C}$. At the indicated times, cells were washed with a medium containing $0.1 \mathrm{M}$ lactose and the cells were collected. After cell-bound radioactivity was measured, cells were sonicated and centrifuged. The supernatant solution was lyophilized and redissolved in $1 \%$ SDS $/ 5 \%$ glycerol $/ 0.001 \%$ bromophenolblue/32 mM Tris-Cl buffer ( $\mathrm{pH} \mathrm{6.8)} \mathrm{for}$ SDS-PAGE analysis and autoradiography.

\section{Assay of Cytotoxicity.}

Cytotoxicity toward four kinds of cells (each $1.6 \times 10^{5}$ cells/well) was determined as the inhibition of intracellular protein synthesis. The rate of protein synthesis was determined by measuring the $\left[{ }^{35} \mathrm{~S}\right] \mathrm{Met} / \mathrm{Cys}$ or $\left[{ }^{14} \mathrm{C}\right]$ Leucine incorporation into trichloroacetic acid-insoluble cell protein at times indicated. Cells were incubated with either the hybrids, ricin D or RNase $\mathrm{A}$ in a $5 \% \mathrm{CO}_{2}$ incubator at $37^{\circ} \mathrm{C}$ for $2 \mathrm{~h}$. [ $\left.{ }^{35} \mathrm{~S}\right] \mathrm{Met} / \mathrm{Cys}$ or 
$\left[{ }^{14} \mathrm{C}\right]$ Leucine $(0.022 \mathrm{MBq} / \mu \mathrm{l} /$ well $)$ was then added and the cells were incubated for the additional desired times. After incubation, cells were detached from the wells with $0.25 \%$ trypsin and sonicated. The lysates were spotted on a Whatmann $3 \mathrm{MM}$ filter paper followed by washing successively with $10 \%$ trichloroacetic acid, dist. water, ethanol and acetone. The dried filter paper was put in ECONOFRUOL followed by measurement with a Beckman LS6000TA liquid scintillation counter. Inhibition of cell-free protein synthesis by ricin B-RNase A hybrid was carried out as described previously (Sakai et al., 1989).

Cytotoxicity was also assessed by measuring viable cells after four kinds of cells (each $5 \times 10^{5}$ cells/well) were incubated with either the ricin B-RNase A hybrid, ricin D or RNase A $\left(1 \times 10^{-7} \mathrm{M}\right.$ each) at $37^{\circ} \mathrm{C}$ for $14 \mathrm{~h}$. Viable cells were counted with a microscope after the cells were mixed with $0.4 \%$ trypan blue and the viability was expressed as $\%$ viable cells against the total cells.

\section{RESULTS}

\section{Preparation and Purification of Ricin B-RNase A hybrid.}

After a careful examination for the derivatization of RNase A with SPDP to obtain 1:1 hybrid, an introduction of 1.2 moles of PDS per mole of RNase A was achieved under the condition described in the METHODS section. Reaction of 5-folds molar excess of the derivatized RNase A with the reduced ricin $\mathrm{B}$ followed by the successive chromatographies through a Sephadex G-100 and CM-cellulose columns yielded mainly a product which was composed of one mole of ricin B disulfide-bridged to 1 mole of RNase A (Fig. 1). The purified ricin B-RNase A hybrid possessed $100 \%$ of hemagglutinating activity toward rabbit erythrocytes and $62 \%$ of RNase A activity toward yeast RNA. The ricin B-RNase A hybrid $\left(5 \times 10^{-7} \mathrm{M}\right.$ and $\left.1 \times 10^{-6} \mathrm{M}\right)$ exhibited the same degree of inhibition of cell-free protein synthesis in the rabbit reticulocyte system as ricin A chain did (Fig. 2).

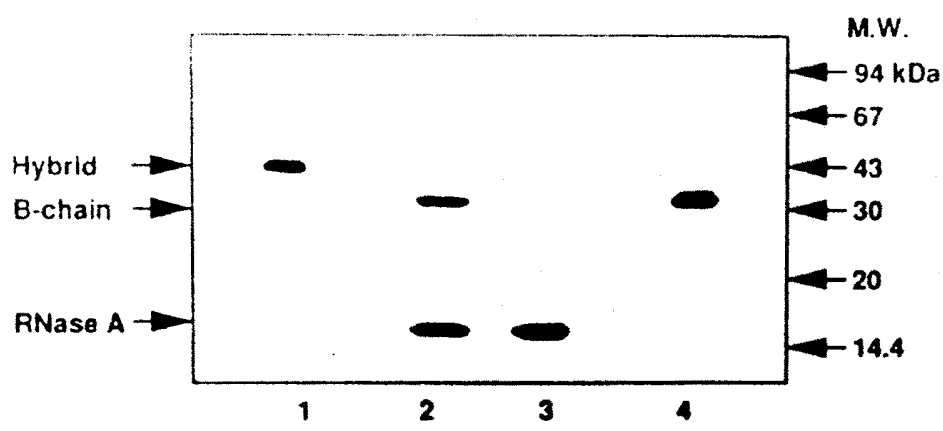

Fig. 1. SDS-polyacrylamide gel electrophoresis of ricin B-RNase A hybrid The hybrid was analyzed by SDS-polyacrylamide gel electrophoresis in $13 \%$ polyacrylamide gel in the presence and the absence of 2-mercaptoethanol. Proteins were visualized by the silver stain kit. Lane 1, the ricin B-RNase A hybrid (under non-reducing condition); lane 2, the ricin B-RNase A hybrid (under reducing condition); lane 3, bovine pancreatic RNase $A$; lane 4 , ricin $B$ chain. 


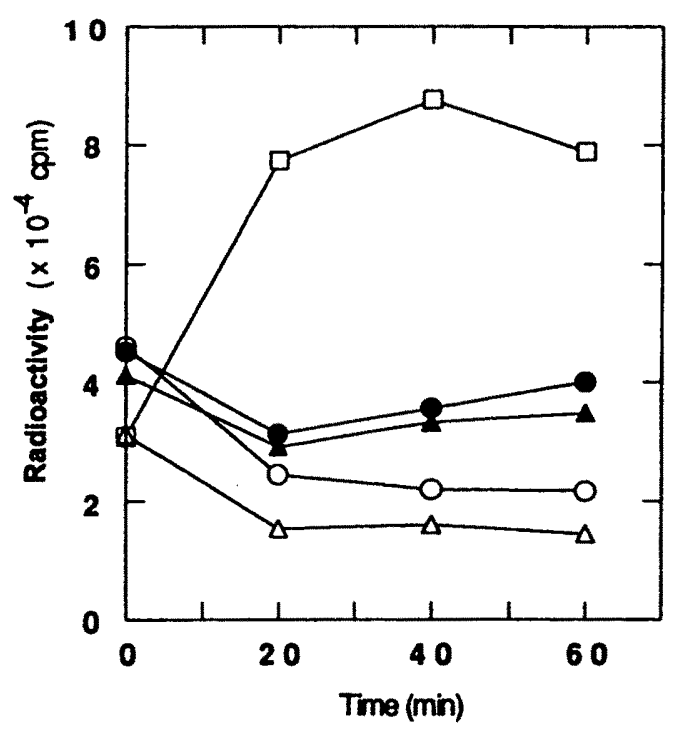

Fig. 2. Inhibition of protein synthesis in a cell-free system by the hybrid

A cell-free protein synthesis was measured as described in "MATERIALS AND METHODS". $\square$ : control; $O: 5 \times 10^{-7} \mathrm{M}$ hybrid; $\triangle: 1 \times 10^{-6} \mathrm{M}$ hybrid; $5 \times 10^{-7} \mathrm{M}$ ricin A chain; $\mathbf{A}: 1 \times 10^{-6} \mathrm{M}$ ricin A chain.

\section{Binding of the ricin B-RNase A hybrid to various cells.}

Binding characteristics of the hybrid was assessed by the competitive binding assay of $\left[{ }^{125} I\right]$ ricin D to rat Leydig, liver cells, HeLa and BeWo cells. Fig. 3 showed that the hybrid inhibited the binding of $\left[{ }^{125} I\right]$ ricin $\mathrm{D}$ to all cells tested as same degree as the cold ricin $\mathrm{D}$.

\section{Cytotoxicity of the ricin B-RNase A hybrid towards various cells.}

As shown in Fig. 4, the hybrid was found to exhibit the inhibition of cellular protein synthesis in all four kinds of cells. Inhibitive effect on the incorporation of $\left.{ }^{35} \mathrm{~S}\right] \mathrm{Met} / \mathrm{Cys}$ by the hybrid was found to start as early as at $30 \mathrm{~min}$ after the incubation as in the case of ricin $\mathrm{D}$, although inhibitive effect of the hybrid $\left(1 \times 10^{-7} \mathrm{M}\right)$ seems to be weaker than that of ricin $\mathrm{D}$ at the same concentration at the later stage. In HeLa cell system, cytotoxic effect of the ricin $\mathrm{B}-\mathrm{RNase} \mathrm{A}$ hybrid was dose-dependent and $\mathrm{ED}_{50}$ of the ricin $\mathrm{B}-\mathrm{RNase}$ A hybrid was $7 \times 10^{-8} \mathrm{M}$ which is about a thousandth of that of ricin $\mathrm{D}$ (Fig. 5). RNase A $\left(1 \times 10^{-7} \mathrm{M}\right)$ alone did not give any inhibition for $4.5 \mathrm{~h}$ to all four kinds of cells.

When HeLa and BeWo cells were treated with either the hybrid, ricin D or RNase A for $2 \mathrm{~h}$ at $37^{\circ} \mathrm{C}$, followed by the additional incubation for $12 \mathrm{~h}$ without reagents, both the hybrid and ricin $\mathrm{D}$ exhibited cytotoxicity (reduction of viable cells) while RNase A did not. In this experiment, cytotoxic effect of the hybrid was weaker than that of ricin D at the same concentration in both cells (Fig. 6). 


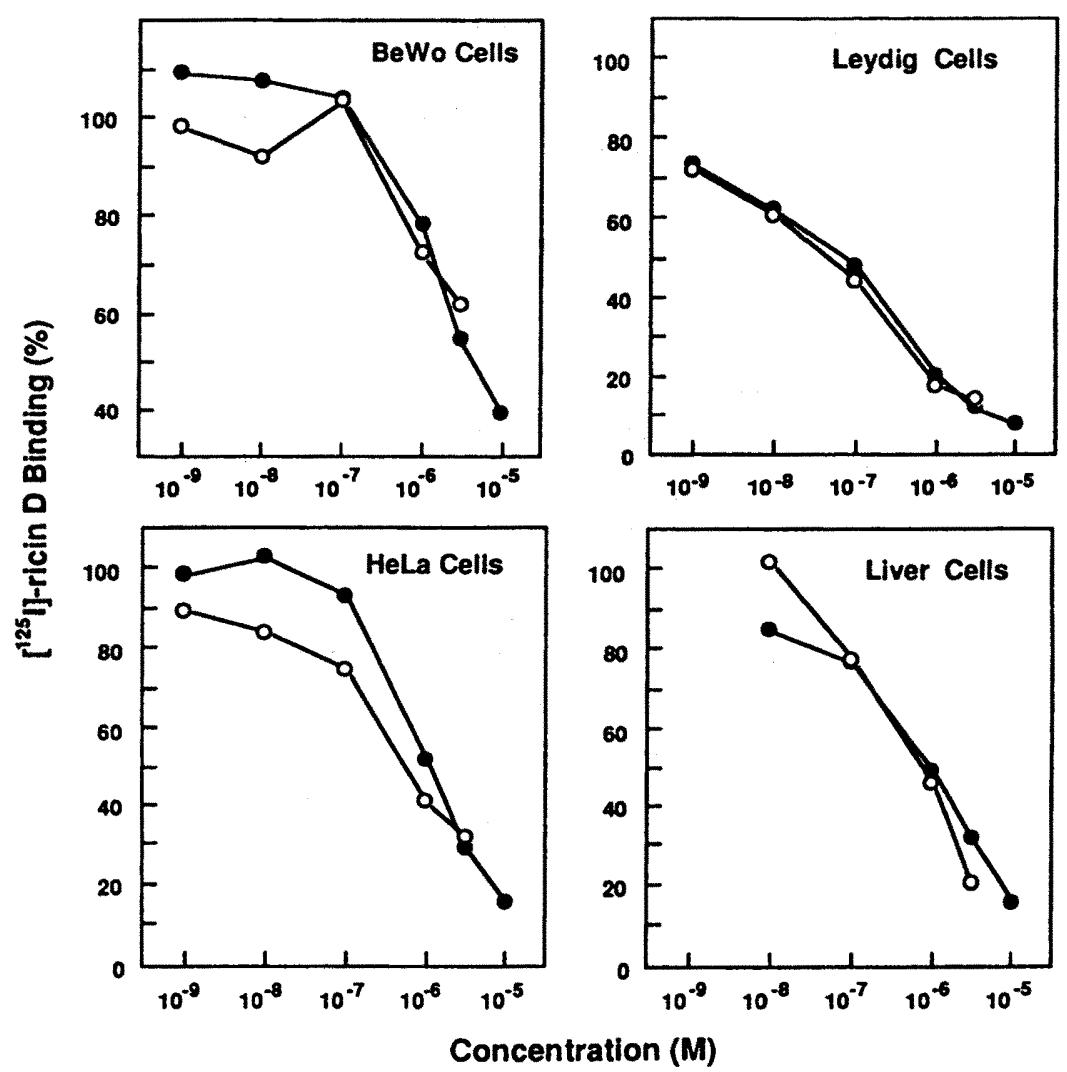

Fig. 3. Inhibition of ${ }^{[25}$ I]ricin D binding to BeWo, HeLa, Leydig and Liver cells by Ricin B-RNase A hybrid and ricin D

Cells were incubated with [ $\left.{ }^{125} \mathrm{I}\right] \mathrm{ricin} \mathrm{D}\left(6.0 \times 10^{5} \mathrm{cpm} /\right.$ well $)$ in the presence of the indicated doses of the hybrid $(\mathrm{O})$ and ricin $\mathrm{D}(\mathrm{)})$ for $1 \mathrm{~h}$ at $4^{\circ} \mathrm{C}$. Bound radioactivity was counted and represented as percentages of that of $\left[{ }^{125} \mathrm{I}\right]$ ricin $\mathrm{D}$ alone.

\section{Internalization of the ricin B-RNase A hybrid into various cells.}

After cells were treated with [ $\left.{ }^{125} \mathrm{~T}\right]$ hybrid or $\left[{ }^{125} \mathrm{~T}\right]$ ricin $\mathrm{D}$ for $3 \mathrm{~h}$ at $37^{\circ} \mathrm{C}$ and washed with the buffer and $0.1 \mathrm{M}$ lactose solution (each 3 times) followed by sonication and separation of the membrane fraction and the lyzate. Determination of radioactivity of the fractions gave degrees of specific binding (A) and radioactivity incorporated into cells (B), and by dividing $\mathrm{B}$ by $\mathrm{A}$ the internalization of the hybrid or ricin $\mathrm{D}$ could be calculated. As shown in Table I, the hybrid bound specifically about $4 \%$ (Leydig cells) $\sim 12 \%$ (HeLa cells) of the total, of which $0.4 \%$ (Leydig) $\sim 1.3 \%$ (HeLa) were in the lyzate bound. It meant that about $10 \%$ (Leydig) $\sim 15 \%$ (BeWo) of the bound hybrid were transferred or internalized into the various cells tested. On the other hand, ricin D bound about $3 \%$ (Leydig) $\sim 11 \%$ (liver cells), of which $1.2 \%$ (Leydig) $\sim 2.7 \%$ (BeWo, HeLa and liver cells) were in the lyzates. It meant that about $22 \%$ (liver cells) $\sim 37 \%$ (Leydig) of ricin D were internalized 

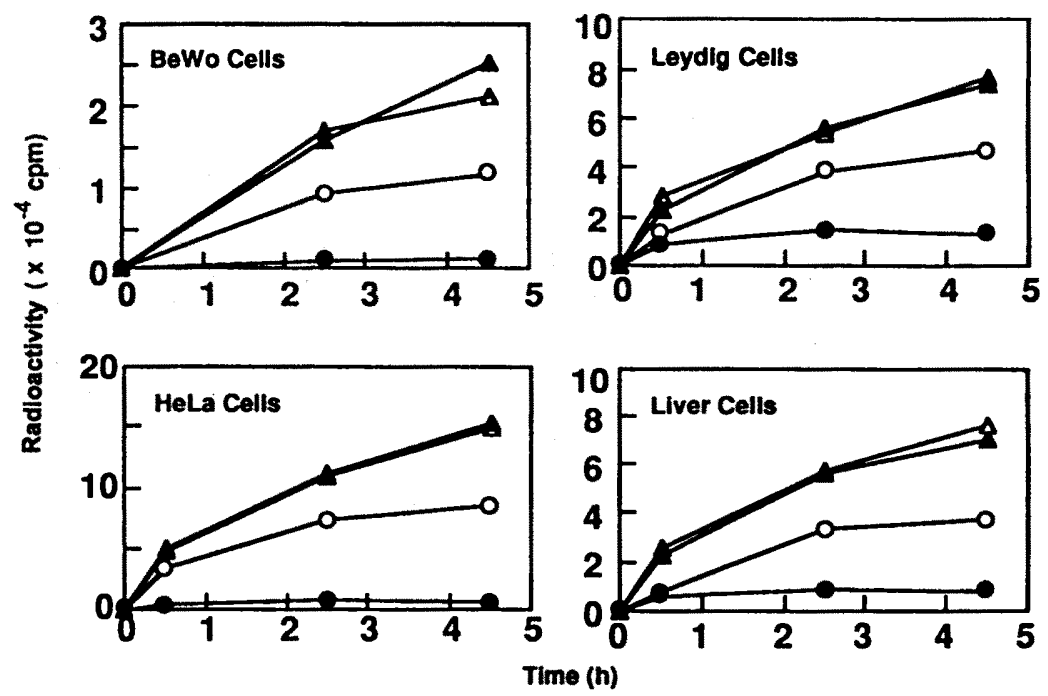

Fig. 4. Inhibition of protein synthesis in BeWo, HeLa, Leydig and Liver cells by ricin B-RNase A hybrid.

Cells were incubated without (control, $\triangle$ ) and with the ricin B-RNase A hybrid $(O)$, ricin D $(\boldsymbol{O})$ and RNase $A(\boldsymbol{A})$ for the indicated times in the presence of [ ${ }^{35}$ S]Methionine/Cysteine. The incorporation of radioactivity into the trichloroacetic acid (TCA) insoluble fraction was determined as described in "MATERIALS AND METHODS".

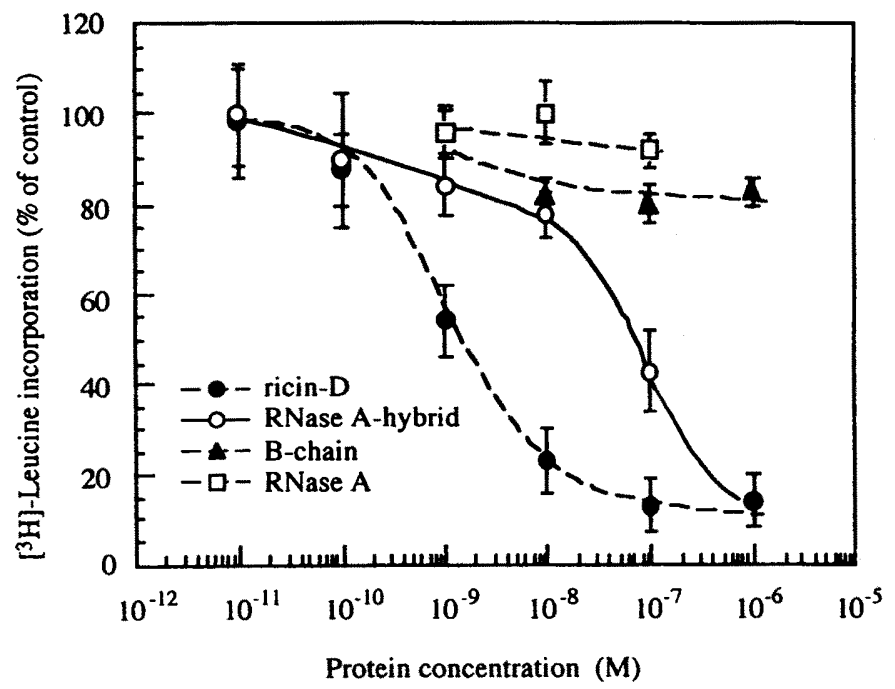

Fig. 5. Inhibition of protein synthesis in HeLa cells by ricin B-RNase A hybrid (dose dependency).

After HeLa cells were incubated with the indicated doses of the ricin B-RNase A hybrid $(O)$, ricin D (O), ricin B chain ( $\mathbf{A})$, and RNase $A(\square)$ for $3 \mathrm{~h}$ at $37^{\circ} \mathrm{C},\left[^{3} \mathrm{H}\right]$ Leucine were added. After $90 \mathrm{~min}$ incubation, protein synthesis was determined by measuring the radioactivity of $\left[{ }^{3} \mathrm{H}\right]$ Leucine incorporation into the trichloroacetic acid insoluble product and was presented as the percentage of a control. 


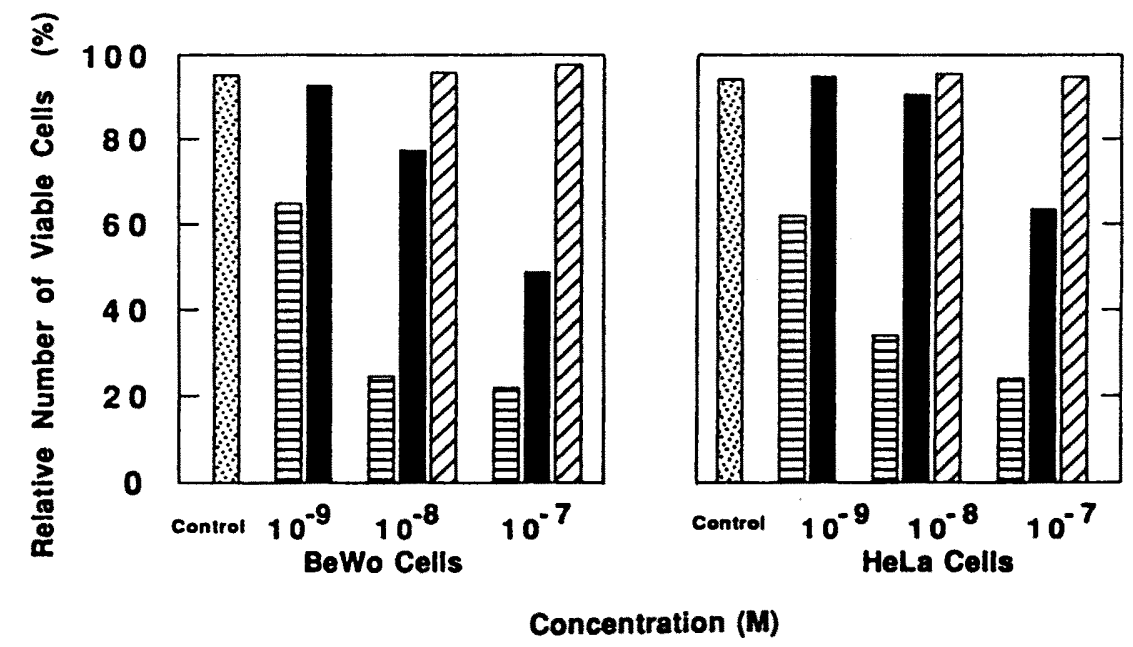

Fig. 6. Cytotoxic effect of ricin B-RNase A hybrid on BeWo and HeLa cells.

Cells $\left(5 \times 10^{5} \mathrm{cells} / \mathrm{well}\right)$ were incubated for $2 \mathrm{~h}$ and $37^{\circ} \mathrm{C}$ in the absence (奐) and presence of the ricin B-RNase A hybrid ( $\mathbf{\square}$ ), ricin D ( additional incubation of $12 \mathrm{~h}$ at $37^{\circ} \mathrm{C}$, the viable cells were counted as described in "MATERIALS AND METHODS" and expressed as the percentage of a control.

Table 1. Incorporation of [125]]ricin B-RNase A hybrid and [ [25I]ricin D into BeWo, HeLa, Leydig and Liver cells

(A)

Specifically Bound cpm
(B)

cpm Incorporated into the Cells

\begin{tabular}{|c|c|c|c|c|}
\hline & \multirow[b]{2}{*}{ Total cpm } & \multirow[b]{2}{*}{ Total cpm } & \multirow[b]{2}{*}{ (A) } \\
\hline & & & & \\
\hline \multirow[t]{4}{*}{ Hybrid } & BeWo cells & $6.40(\%)$ & $0.943(\%)$ & $14.7(\%)$ \\
\hline & HeLa cells & 11.9 & 1.28 & 10.8 \\
\hline & Leydig cells & 3.98 & 0.388 & 9.75 \\
\hline & Liver cells & 9.02 & 0.966 & 10.7 \\
\hline \multirow[t]{4}{*}{ Ricin D } & BeWo cells & 7.77 & 2.61 & 33.6 \\
\hline & HeLa cells & 9.28 & 2.71 & 29.2 \\
\hline & Leydig cells & 3.15 & 1.17 & 37.1 \\
\hline & Liver cells & 10.8 & 2.38 & 22.0 \\
\hline
\end{tabular}

Cells $\left(8 \times 10^{5}\right)$ were incubated with $\left[{ }^{125} \mathrm{I}\right]$-hybrid or $\left[{ }^{125} \mathrm{I}\right]$-ricin $\mathrm{D}$ for $3 \mathrm{~h}$ at $37^{\circ} \mathrm{C}$. 


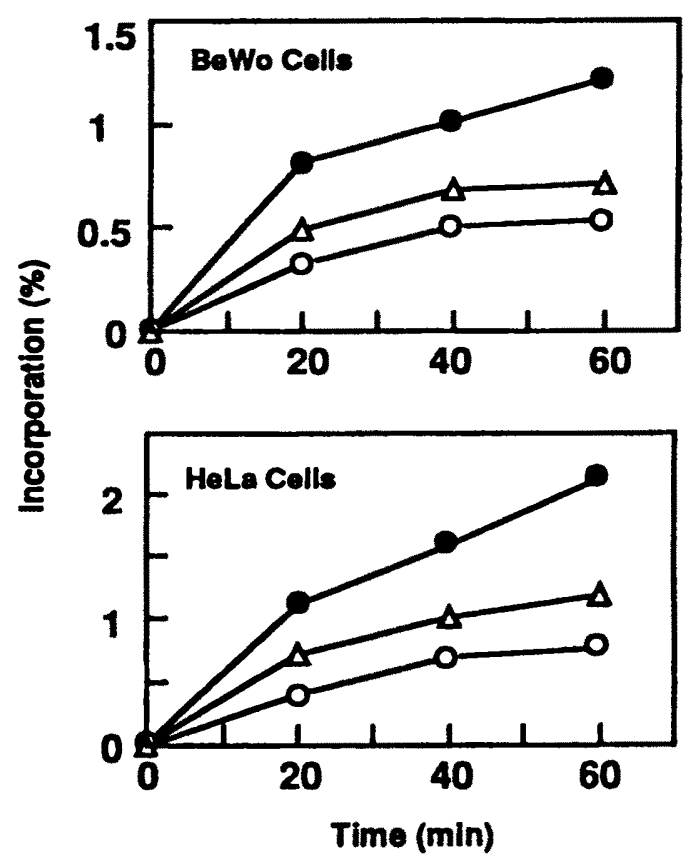

Fig. 7. Effect of ricin A chain for incorporation of [ $\left.\left.{ }^{125}\right]\right]$ ricin $B-R N a s e$ A hybrid into BeWo and HeLa cells.

Cultured cells were incubated with each $1 \times 10^{-7} \mathrm{M}$ of $\left[{ }^{125} \mathrm{I}\right] \mathrm{ricin}$ B-RNase A hybrid (O), $\left[{ }^{125} \mathrm{I}\right]$ ricin $\mathrm{D}(\mathrm{O})$, and $\left[{ }^{125 \mathrm{I}}\right]$ ricin B-RNase A plus ricin $A$ cahin $(\triangle)$ for the indicated times at $37^{\circ} \mathrm{C}$. After cells were washed 3 times with $0.1 \mathrm{M}$ lactose, the radioactivity of the pellets was counted with an Aloka ARC-300 $\gamma$-counter and expressed as the percentage of the total radioactivity included.

into cells. These results clearly showed that the degree of internalization of the hybrid into any of the cells tested were lower than that of ricin D. Fig. 7 shows that the presence of ricin A chain could help internalization of the hybrid into the cells although the effect was not enough to achieve the full degree of internalization of ricin D itself.

\section{Analysis of internalized molecules.}

After the cells were incubated with [ ${ }^{125}$ I]ricin B-RNase A hybrid or [125I]-ricin D at $37^{\circ} \mathrm{C}$ for various times and washed 3 times with the buffer containing $0.1 \mathrm{M}$ lactose, the lyzate fractions were analyzed with SDS-PAGE followed by autoradiography. As shown in Fig. 8, in any kind of cells, radioactivity was found at the position of $14.4 \mathrm{kDa}$ which corresponded to the molecular weight of RNase A in the case of the hybrid at $1 \mathrm{~h}$ after incubation. In the case of ricin $D$, most of the radioactivity was found at the position of $64 \mathrm{kDa}$ which corresponded to the molecular weight of intact ricin $\mathrm{D}$ after $1 \mathrm{~h}$, although radioactivity associated with low molecular weight polypeptide(s) increased after $3 \mathrm{~h}$. 

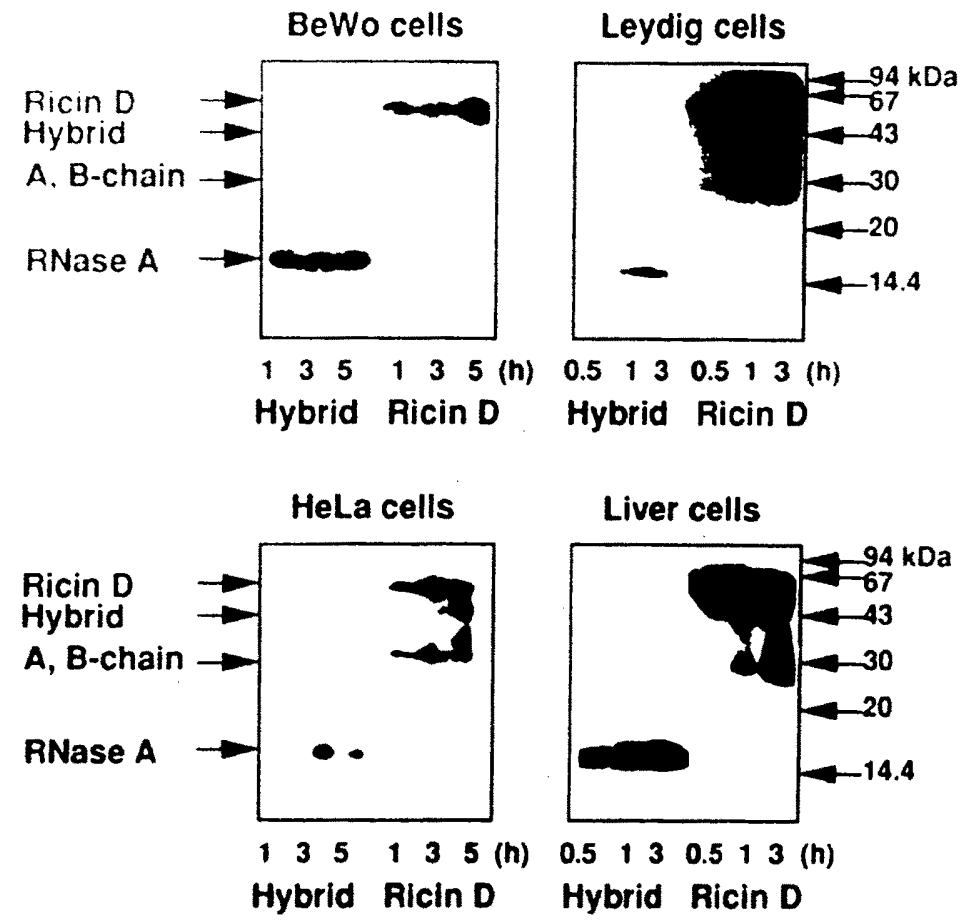

Fig. 8. Internalization of [125I]ricin B-RNase A hybrid and [ $\left.{ }^{125} I\right]$ ricin D by BeWo, HeLa, Leydig and Liver cells.

Cells were incubated with [25I]ricin B-RNase A hybrid and [ $\left.{ }^{125}\right]$ ricin D for the indicated times at $37^{\circ} \mathrm{C}$. After the cells were washed 3 times with $0.1 \mathrm{M}$ lactose, the pellets were analyzed by SDS-PAGE and autoradiography as described in "MATERIALS AND METHODS".

These results seem to indicate that an artificial disulfide bridge introduced into the hybrid was weaker than that is originally present in ricin $\mathrm{D}$.

\section{DISCUSSION}

Ricin $\mathrm{D}$, a toxic lectin ( $\mathrm{Mr}=64,000)$ in castor bean seeds (Ricinus communis $L$.), consists of two polypeptide chains (A and B chains) which are linked by a single disulfide bond (Hara et al., 1975). Later, ricin was classified into type II of the ribosome-inactivating proteins (RIPs), a family of toxic proteins produced by plants that inactivate eukaryotic ribosomes. The $\mathrm{B}$ chain $(\mathrm{Mr}=34,000)$ of ricin can bind to the cell surface glycoconjugate containing non-reducing terminal galactose, generally called "ricin receptors". The binding of the $B$ chain to its receptors causes the internalization of ricin. After internalization, the free A chain ( $\mathrm{Mr}=30,000)$, but not the A chain linked to the $\mathrm{B}$ chain, inactivates vital cytosolic components of protein synthesis machinery in a catalytic 
manner, i.e., the cleavage of a single adenine residue from eukaryotic 28S RNA in the 60S ribosomal subunit (Endo et al., 1987). Major requirements for the expression of cell toxicity by ricin, therefore, are the binding of ricin to the target cells, the internalization and the cleavage of disulfide bond between A and B chains, and the attainment of free A chain to the cytosol. It has been suggested that the A chain penetrates from the endoplasmic reticulum (ER), implicating the translocation of ricin from the endosomes to the ER via a retrograde transport through the Golgi apparatus during intoxication (van Deurs et al., 1988).

When added to cells, ricin is highly toxic since it has both a cell-binding portion (B chain) and an enzymatic ribosome-inactivating portion (A chain). Similar to bacterial toxins such as Pseudomonas exotoxin and Diphtheria toxin, ricin has catalytic property and only a small number of molecules need to reach the cytosol in order to inactivate enough ribosomes to kill the cell. From these reasons, ricin or its A chain has been the most popular choice for use as the toxin portion of immunotoxins (Youle and Neville, 1982). An immunotoxin, which has been aimed to the therapeutic use for cancer and other diseases, is a hybrid protein containing a whole ricin or A chain disulfide-bridged to cancer-specific antibody or various growth factors. Although much effort has been paid to prepare an ideal immunotoxin, immunotoxins thus far reported were found to be less potent than ricin itself in addition to several drawbacks such as instability, side-effects, production of antibody. Most of these drawbacks come from the present situation that the precise mechanism of cell intoxication by ricin has not yet understood (Vitetta, 1986). Which is more effective for internalization, binding of immunotoxin to cells surface via growth factor-its receptor or via antigen-antibody complex or via a lectin-cell surface sugar interaction? What is a mechanism by which interpolypeptide disulfide bridge is cleaved and followed by translocation of catalytic A chain to the cytosol ?

Comparative studies on immunotoxins prepared using an intact type II RIP, ricin, and immunotoxins prepared with only the A-chain of ricin have shown that hybrid toxins consisting of the intact toxin are more potent than the A chain hybrids. The toxicity of ricin A chain containing immunotoxins has been found to be potentiated by simultaneous addition of free ricin B chain, thereby suggesting a role for the B chain in addition to cell surface binding (Ramakrishnam et al., 1992; Thrush et al., 1996). It was also shown that $\mathrm{B}$ chain lectin activity toward galactose binding sites of the cells is essential (Timar et al., 1991).

This study was aimed to explore a role of ricin B chain in the binding and internalization of the hybrid into various types of cells. The present results described above clearly indicated that ricin B chain, a constituent polypeptide of ricin D and a lectin itself, is able to transfer a foreign protein into various types of cells as a SS-bridged hybrid, although the rate of internalization was $1 / 3 \sim 1 / 2$ less than that of ricin $D$. By employing the ricin B-RNase A hybrid (1:1 hybrid), we could demonstrate that the ricin B-RNase A hybrid which bound specifically to the transformed and normal cells could exhibit cytotoxicity despite that RNase A alone failed to kill these cells. Moreover, ricin B chain could facilitate the internalization of a foreign protein such as RNase A into four different kinds of cells although its cytotoxic effect was less potent than ricin D. It was inferred that the hybrid (ricin B-RNase A) first bound to the cell membrane via B chain followed by internalization into the cells and by release of RNase A into the cytosol which resulted 
in the hydrolysis of RNAs essential for the cellular activity and inhibited the protein synthesis, finally causing the cell death. That the ricin B-RNase A hybrid was less potent than ricin $D$ could be explained by several reasons as follows: less internalization and instability of the synthetic disulfide introduced. Fig. 9 shows the cytotoxic effect of several protein derivatives prepared in this laboratory on the cultured cells. In any cases, no protein derivatives were as toxic as ricin D itself. For internalization, the hCG-ricin A hybrid, a hormonotoxin, first binds to hCG receptors on the cell surface of the Leydig cells, the anti BeWo IgG-ricin A hybrid, an immunotoxin, binds to surface antigens of BeWo cells, ricin D and ricin B-RNase A hybrid bind to surface terminal galactose-containing carbohydrate chains of the many eukaryotic cells, while liposome-encapsulted ricin could be phagosized without any specific receptors. High toxicity of intact ricin $\mathrm{D}$ could be derived from effective internalization of the intact ricin $\mathrm{D}$ molecule in which the disulfide-bridged $\mathrm{A}$ and $\mathrm{B}$ chains make sufficient spatial arrangement to be internalized. In our experiment, the addition of the A chain to the reaction mixture helped partly the internalization of the ricin B-RNase A hybrid into HeLa cells.

Finally, together with the results obtained previously with the hCG-B hybrid, it was inferred that a hybrid protein in which the ricin $B$ chain is disulfide-bridged with a new protein could be useful to introduce a foreign protein into a certain type of cells.

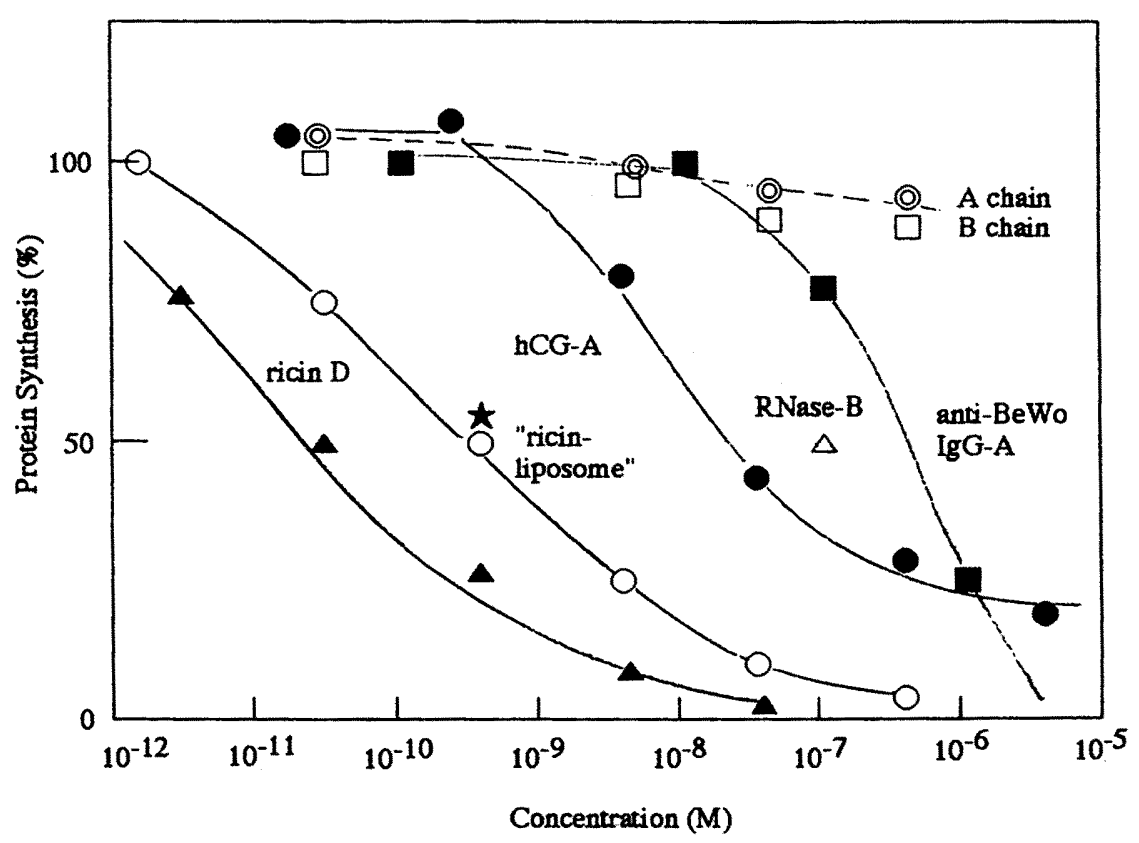

Fig. 9. Cytotoxic effects of ricin derivatives towards the cultured cells.

Inhibition of protein synthesis was determined as described in "MATERIALS AND METHODS" employing rat Leydig cells for ricin D (O), hCG-A (O), anti BeWo IgG-A (G), ricin B-RNase A $(\triangle)$, ricin A chain (O), ricin B chain or hCG-B $(\square)$, and HeLa cells for ricin D $(\boldsymbol{A})$ and liposome-encapsulated ricin $\mathrm{D}(\boldsymbol{\star})$. 


\section{REFERENCES}

Endo, Y., K. Mitsui, M. Moriguchi and K. Tsurugi 1987 The mechanism of ricin and related toxins on eukaryotic ribosomes. J. Biol. Chem., 262, 5908-5912

Fulton, R. J., D. C. Blakey, P. P. Knowles, J. W. Uhr, P. E. Thorpe and E. S. Vitetta 1986 Purification of Ricin A1, A2, and B Chains and Characterization of Their Toxicity. J. Biol. Chem., 261, 5314-5319

Hara, K., M. Ishiguro, G. Funatsu and M. Funatsu 1974 An Improved Method of the Purification of Ricin D. Agric. Biol. Chem, 38, 65-70

Hara, K., M. Ishiguro, G. Funatsu and M. Funatsu 1975 Physical, Chemical and Physiological Properties of S-CM Subunits of Ricin D. Agric, Biol. Chem., 39, 1631-1637

Hara, K., M. Ishiguro, G. Funatsu and M. Funatsu 1975 Structure-Toxicity Relationship in Subunit Structure of Ricin D. Agric. Biol. Chem., 39, 1639-1644

Morino, H., R. Sakakibara and M. Ishiguro, 1995 The binding of ricin to its receptor is not required for the expression of its toxicity. Biol. Pharm. Bull., 18, 1770-1772

Oda, T. and G. Funatsu 1979 Cross-linking of the Two Constituent Polypeptide Chains of Ricin D with N, N'-O-Phenylenedimaleimide. Agric. Biol. Chem., 43, 547-554

Ohwaki, K., R. Sakakibara and M. Ishiguro, 1994 Antibody against a peptide corresponding to the extracellular domain of the luteinizing hormone/chorionic gonadotropin receptor stimulates testosterone production in rat Leydig cells. J. Biochem., 115, 596-601

Ramakrishnan, S., D. Fryxell, D. Mohanraj, M. Olson, and B. Y. Li, 1992 Cytotoxic conjugates containing translational inhibitory proteins. Ann. Rev. Pharmacol. Toxicol., 32, 579-621

Sakai, A., R. Sakakibara and M. Ishiguro 1989 Human Chorionic Gonadotropin-Ricin A chain Hybrid Protein: A Hormone Analog for the Study of Signal Transduction. J. Biochem., 105, 275-280

Sakai, A., R. Sakakibara, K. Ohwaki and M. Ishiguro 1991 Steroidogenic Activity of Synthetic Hybrid Molecules Composed of Human Chorionic Gonadotropin and Either the A or B Chain of Lectin Ricin or Horseradish Peroxidase. Chem. Pharm. Bull., 39, 2984-2989

Sharma, S., S. K. Podder and A. A. Karande 1999 Comparative studies on kinetics of inhibition of protein synthesis in intact cells by ricin and a conjugae of ricin B-chain with momordin. Molec. Cellul. Biochem., 200, 133-141

Thrush, G. R., L. R. Lark, B. C. Clinchy and E. S. Vitetta, 1996 Immunotoxins. An update. Ann. Rev. Immunol., 14, 49-71

Timar, J., D. P. McIntosh, R. Henry, A. J. Cumber, G. D. Parnell and A. J. S. Davies, 1991 The effect of ricin $\mathrm{B}$ chain on the intracellular trafficking of an A chain immunotoxin. $\mathrm{Br}$. J. Cancer, 64,655-662

Van Deurs, B., K. Sandvig, O. W. Peterson, S. Olsnes, K. Simons and G. Griffiths 1988 Estimation of the amount of internalized ricin that reaches the trans-Golgi network. $J$. Cell Biol., 106, 253-267

Vitetta, E. S. 1986 Synergy between immunotoxins prepared with native ricin A chains and chemically modified ricin B chains. J. Immunol., 136, 1880-1887

Youle, R. J. and D. M. Neville 1982 Kinetics of protein synthesis inactivation by ricin-anti-Thy 1 antibody hybrids. J. Biol. Chem., 257, 1598-1600 